\title{
The Civilizing Mission and Indirect Rule in Northern Nigeria: A Contradiction
}

\author{
Lamont DeHaven King $^{1}$ \\ ${ }^{1}$ Department of History, James Madison University, USA \\ Correspondence: Dr. Lamont DeHaven King, Department of History (MSC 2001), James Madison University, 800 S. \\ Main St., Harrisonburg, VA 22807, USA.
}

Received: June 6, 2016

Accepted: June 16, 2016

Available online: June 22, 2016

doi:10.11114/ijsss.v4i8.1688

URL: http://dx.doi.org/10.11114/ijsss.v4i8.1688

\begin{abstract}
This paper examines the compatibility of the Civilizing Mission with the British colonial doctrine of Indirect Rule. Focusing on Northern Nigeria, it shows that Lord Lugard, the primary architect of the system, did not exclude missionaries from the area. Instead, subsequent colonial administrators limited missionary contact and education because they feared that the ideas of equality in Christianity would undermine both colonial authority and what they considered to be a traditional Islamic conservatism that enhanced law and order. In so doing, British administrators after Lugard often redefined custom by appointing pliable, non-aristocratic leaders in order to rule directly through them. Specifically in the emirate of Katsina, this governmental strategy resulted in little attention being paid to the development of western oriented education during the first two decades of British rule. More generally, this intersection of colonization, religion, education and the redefinition of custom in Northern Nigeria created a polity that was geared more to the needs of colonial power than to any dissemination of the ideals of western individualism and progress.
\end{abstract}

Keywords: Northern Nigeria, Indirect Rule, Civilizing Mission, Lugard, Colonial Administration

\section{Introduction}

The uniting of the hemispheres in the fifteenth century led to the eventual colonization of the New World by Europe. Africa, however, was not colonized to any great degree during this "Age of Exploration." Indeed, until the end of the nineteenth century, the European presence in Africa, with the notable exceptions of South Africa and Algeria, was confined to coastal areas. Consequently, even the considerable duration of the slave trade was not accompanied by a significant European cultural influence on the African continent (Northrup, 2009). It is not surprising, then, that when scholars seek to explain the reasons for the eventual colonization of Africa by European states, "the Civilizing Mission," is offered as one of among three primary reasons---the other two being economic gain and the emergence of nationalism in Europe. Armed with the evolutionary assumptions of Social Darwinism, the Civilizing Mission is offered as a rationale that helped to mask economic exploitation and explain many of the negative consequences of this European colonial enterprise. ${ }^{1}$ Of course, the assumptions of progress, individualism, and development inherent in these imperialistic endeavors have been critiqued by scholars working in many different fields (Clastres, 1977; Rodney, 1982; Onimode, 1982; Wolf, 1997; Asante, 2014). And, consequently, the relationship between the bible and the gun has been readily acknowledged in academic circles. It has also been shown that individual missionaries had a vested interest in presenting Africans in as negative a light as possible to enhance the perceived effectiveness of their religious activities (Chamberlain, 1994, pp. 24-25). Though this paper does not explore the sincerity of specific missionaries, it does focus on the general incompatibility of missionary education with the British administrative doctrine of Indirect Rule in Northern Nigeria.

Indirect Rule is literally rule through local elites and, as such, it has been utilized in colonial enterprises throughout history (See de St. Croix, 1981). The necessities of manpower and money for controlling conquered populations often made the cooperation of defeated elites an imperative. Nevertheless, as a clearly articulated doctrine, an important step was taken when Britain adopted the policy of preserving the Indian states instead of extending its "direct" rule in the area. However, Indirect Rule reached its zenith with the British conquest of the Sokoto Caliphate in the area that was ultimately to become Northern Nigeria. By 1922, Lord Lugard, who had cut his imperial teeth in India and who had also by then relinquished the governorship of Nigeria, had written The Dual Mandate in British Tropical Africa (1965a), which is considered to be the official handbook of Indirect Rule. But how did this official doctrine articulate with the 
Civilizing Mission - the duty to Christianize and otherwise educate Africans in the "superior aspects" of European civilization? I contend that the Civilizing Mission was not a primary goal of Indirect Rule in Northern Nigeria. As Mahmood Mamdani (1996) notes, Indirect Rule was, in fact, "decentralized despotism":

... Alongside received law was implemented a customary law...For the subject population of natives, indirect rule signified a mediated-decentralized-despotism...Britain led the way in fashioning a theory that claimed its particular form of colonial domination to be marked by an enlightened and permissive recognition of native culture...the colonial state claimed this process to be no more than a deference to local tradition and custom (Mamdani, 1996, pp. 17, 25).

Keeping Mamdani's concept of decentralized despotism in mind, while simultaneously focusing on Northern Nigeria, the pinnacle of Britain's Indirect Rule policy, this paper will 1) examine political organization in the area that was to become Nigeria; and 2) analyze governmental policies on religion, education, and custom in order to show how these policies contradict the basic tenets of the Civilizing Mission.

\section{The Colonization of Northern Nigeria}

The area that ultimately became the British colony of Nigeria can be roughly divided into three major ethnic regions: Hausa-Fulani in the north, Yoruba in the southwest and Igbo in the southeast. The Hausa-Fulani speakers were organized into a loose confederation of Islamic states known as the Sokoto Caliphate; the political and spiritual leader of the empire was the caliph. However, due to the size of the Caliphate and lack of communications, it was impossible for the leader in Sokoto to govern directly. Consequently, he delegated authority to emirs who, according to Islamic law, governed as his deputies. If an emir died or was removed from power by the caliph, a local counsel of electors usually prepared a list of suitable candidates for Sokoto's approval. Obedience to Sokoto gave the emirs political legitimacy and revenues derived from the emirates were the primary source of the Caliphate's wealth. There were no representative institutions; all political officials served at the pleasure of either the caliph or the various emirs. By the end of the nineteenth century, the Sokoto Caliphate was part of the dar-al-Islam, having established enduring connections with Kanem-Bornu, Cairo and the Maghreb (Last, 1967; H.A.S. Johnston, 1967). Despite the fact that the caliph's symbolic authority was acknowledged by all of the emirates, there were still independent enclaves within the Caliphate's borders and many Hausa and Fulani had not converted to Islam. Moreover, because this decentralization impeded the development of a standing army, after initial incursions by the Royal Niger Co. in 1897, Lugard's West African Frontier Force began the conquest of the various emirates one-by-one and by 1903 the British were firmly in control of the region (Adeleye, 1971).

In order to understand the structure of Indirect Rule that was established in the Northern region, the focus of this essay, it is also necessary to briefly examine the socio-political organization of the Southern region. Prior to colonization, the Igbo speakers of the southeast can be broadly divided into "presidential monarchies" and "village republics." Though there were regional differences, all were similar in that they were associations "of fellow citizens who have agreed to cooperate to maintain law and order and promote social welfare" (Afigbo, 1972a, p. 20). Among the Igbo, elders were respected and served as lineage heads, representing the channel between the living and the dead ancestors. Individuals could also acquire titles which presupposed extraordinary gifts of honor, judgment and ability. However, neither elders nor titled men dominated decision making. Decisions were obtained by consensus after free debate in which all members of the community participated (Okonjo, 1974, pp.17-18). In short, the Igbo polities were primarily direct democracies. Among the Yoruba-speaking peoples of the southwest, city-states predominated -- each with its own chief and political institutions. In a typical state, like Oyo or Ibadan, secret societies also had political power. Additionally, though legislative, judicial, and executive powers were vested in him, the ruler had to consult his council of state and often depended on priestly religious sanctions to enforce his authority (Okonjo, 1974, p.14).

Although Catholic priests had attempted to introduce Christianity into the Hausa states as early as the eighteenth century, a meaningful missionary presence in the area that was to become Nigeria was first felt in the southern region in the nineteenth century. The British colony of Sierra Leone created some of West Africa's earliest missionaries, as well as newspapers and secondary schools. It is no coincidence that the first Anglican Bishop of Nigeria was Samuel Ajayi Crowther. An Oyo by birth, Crowther was sold into slavery in the early 1820s and ended up not in Brazil or Cuba, like many other Yoruba speakers in the nineteenth century but, through the efforts of the British Anti-Slavery Squadron, in Sierra Leone. From there, he later traveled on expeditions into southern Nigeria along the Lower Niger in 1841 and 1857 (Northrup, 2009, pp. 145-146.). As a Church Missionary Society (C.M.S) Anglican missionary, he translated the bible into Yoruba; he also helped to introduce Christianity to the Northern Region between 1869 and 1888 . By the end of the nineteenth century the Wesleyans, who joined the C.M.S. in the area, had "come to believe that the Hausa would be the providential instrument for the Christianization" of much of the rest of Africa (Ayandele, 1966, p. 504).

Despite the fact that wholesale conversion failed, it is important to note that during this period Northern Nigerian rulers were tolerant of Christian missionaries, as long as they "were friendly, cooperative and tactful." And even after 1900, 
when they clearly associated missionaries with the imperialistic activities of Goldie's Royal Niger Co. and Lugard's West African Frontier Force, "Muslim rulers of Northern Nigeria entertained no religious fear of the missionaries" that preached a religion for which they essentially had contempt (Ayandele, 1966, p. 507). Nevertheless, by 1918, the British administration had disassociated itself from missionaries and directly opposed missionary activity, not only in predominantly Muslim areas but in "pagan" districts of the North as well. Why did British administrators ultimately prohibit the establishment of Christian missions in the northern region?

\section{Religion and Government}

By 1901 Lugard had befriended Dr. Walter Miller, a dedicated C.M.S. missionary in Hausaland, and "promised to tell the Emirs that the missionaries were his brothers." The emirs should, consequently, consent to missionaries coming into their country after it was "pacified." In the same year, Lugard gave permission to Miller to open a mission station in Katsina, if the emir would not object. And, in 1903 the Emir of Bida also welcomed the C.M.S. and the Toronto Industrial Mission. In fact, during Lugard's early administration, C.M.S missionaries established stations in Zaria and invitations came to them from Kano as well (Ayandele, 1966, pp. 515-516). According to Ayandele (1966):

It is essential to note that in the period 1900 to 1906 there were no complaints by the missionary world about Northern Nigerian administration restricting Christian enterprise in the territory. This was why many Christian missions expressed appreciation to Lugard for his policy and why the largest of them, the Church Missionary Society, regretted the termination of his authority in 1906 ( pp. 515-516).

Lugard left Northern Nigeria for Hong Kong in 1906, three years after the region was conquered. He did not return until 1912 to oversee the amalgamation of the Protectorates of Northern and Southern Nigeria as Governor and Commander in Chief. ${ }^{2}$ Though many, like the emirs of Katsina and Bida, appreciated western technology and welcomed missionaries, almost every year after 1906 the administration rejected C.M.S applications to establish missions in the North. Though missionary activity had been welcomed in the North, missionary activity under early British colonial rule was limited when compared to missionary activity in the South. For example, by 1914 there were only 650 pupils in mission schools in all of Northern Nigeria; in the Yoruba district of Abeokuta alone there were over 4,000 (Ayandele, 1966, pp. 519-20). It was not until 1924 that a mission station was actually permitted to operate in Kano, and then only in the sabon gari (new town) district that was inhabited primarily by southerners (Ayandele, 1966, p. 518). This sabon gari system in the North will be discussed below within the context of Lugard's Political Memoranda (1965b), the circulars and instructions on Indirect Rule that were composed for his principle assistants in the field between 1902 and 1904. These correspondences, his initial guidelines on African administration, were subsequently edited, elaborated upon, and compiled in 1906.

British rule in Northern Nigeria was based on conquest, not on treaty. Moreover, in 1903 the population of Northern Nigeria was estimated at more than 7 million and Lugard had only 231 civil European officers. By 1906 the ratio of European officers was 1 to 2,900 square miles and 1 to 45,000 Africans (Okonjo, 1967, p. 27). For the British, then, Indirect Rule was a matter of expediency rather than obligation (Okonjo, 1967, p. 46). Consequently, in his Political Memoranda (1965b), Lugard proposed that "government utilises and works through the native chiefs, and avails itself of the intelligence and powers of governing of the Fulani caste in particular..." The primary duty of the British Resident was to promote this policy through the establishment of native courts (Okonjo, 1967 p. 37). In order to give practical and legal effect to the cardinal principle of Indirect Rule - governing each state through its indigenous political institutions--Lugard enacted the Native Authority Proclamation. Under this law, the High Commissioner had the power to appoint a chief to administer an area (Okonjo, 1967, pp. 44-50). The ramifications of the Proclamation will be discussed in more detail below in the section on custom. However, for now, it is important to note that even though there was little fear of mass conversion, to the Caliph of Sokoto, any accommodation with the British could have been construed as a denial of Islam by his adherents. In fact, many Fulani emirs gave serious consideration to flight from what they considered to now be infidel territory. Hence a good deal of the content of Indirect Rule was conceived so that it would not impinge upon religious freedom (Okonjo, 1967, pp. 32-35).

After his defeat in 1903, Lugard had promised the Emir of Sokoto that "the British administration would not interfere with Islam." He did not, however, enter into a treaty that stipulated the exclusion of missionaries in the former caliphate. He simply agreed that Muslims would not be forced to accept Christianity, but that did not imply that missionaries would be prevented from operating in Muslim districts. And, as noted above, it was not until after Lugard's departure in 1906 that the British began to adopt an anti-missionary policy (Ayandele, 1966, pp. 515-516). It is important to note further, that this missionary exclusion began to be justified as a violation of Indirect Rule. An example of this anti-missionary feeling within the context of Indirect Rule in Northern Nigeria was clearly expressed by Temple in Native Races and Their Rulers (1918), a book that he wrote after his retirement from colonial service. In this work, "missionary propaganda, which had its raison d'etre the changing of the African's ethos and lifestyle," was seen as 
"diametrical to the indirect rule philosophy and had no place in the Muslim areas of the north" (Allyn, 1976, p. 48). Lugard's agreement not to interfere with the practice of Islam was now being used to exclude missionaries.

Subsequent administrators in Nigeria altered Lugard's position on missionaries for two main reasons. First, missionaries rivaled their position of authority in the community-- they worked more closely with the masses and "never hesitated" to bring "acts of injustice or oppression" committed by the administration to the attention of the British public and the Colonial Office. For example, by 1908 Miller had become a "thorn in the side" and a "dangerous man" to a Colonial Office that "tired of his exposure and denunciation of the atrocities being committed by British administration in Northern Nigeria." Second, missionaries preached a doctrine of equality, which undermined the respect of the masses for traditional authority, a cardinal principle of Indirect Rule (Olusanya, 1967, pp. 243-244). A general feeling emerged among Lugard's successors that the Native Authorities should be "preserved as living museums" and their exposure to any contact with the outside world was frowned upon. Consequently, after Lugard's departure in 1906, "every attempt was made to prevent the infiltration of western ideas any further into Northern Nigeria." This attitude was a product of an interpretation of Indirect Rule that maintained that "the first duty of a political officer is to keep Native Administrations unspotted from the world and to shield and protect them from all subversive outside influences" (Olusanya, 1967, p. 243). In the eyes of the post-Lugard administrators, something had to be done to impede the proliferation of these western forces. And, the exclusion of missionaries was one measure taken by the new British rulers. However, though Lugard's promise to the Caliph of Sokoto in 1903 could perhaps justify banning missionaries, it could not be used to ban traders. To that end, the British also took advantage of the sabon gari system.

\section{Education and Exclusion}

It is clear from early Arabic sources that traders that migrated into Hausaland followed a traditional pattern of settlement in the "strangers' quarters." They were usually under the immediate authority of one of their own leaders. However, they could not breach the ultimate authority of their sovereign host. This traditional pattern for the governance of strangers' quarters underwent important modifications during the colonial period. After 1911, the British government introduced a more rigid segregation of these areas from the local population (Allyn, 1976, pp. 1-2). And, by 1914, sabon gari settlements, populated primarily by southerners that worked for the expanding railroad system, as government clerks, and as employees of the European firms, were well established in Kano and Zaria. By 1917 the Township Ordinance, which regularized the sabon gari system throughout Nigeria, legally established the areas as Second Class Townships throughout the colony. However, the policy was applied differently in the North and the South (Olusanya, 1967, p. 247). ${ }^{3}$ For example, in the South, the sabon gari were located within the city walls, in the North they were usually outside the walls, thereby providing a distinct physical separation between the indigenous community and the strangers' quarters. Moreover, taxes collected in the North also went directly to the Township Fund and not to the Native Authority, as they did in the South. Finally, and most importantly for our purposes here, because of this special relationship with the European Township, the northern sabon gari communities were granted access to the British legal system; they were given an extra-territorial status that removed them from the Islamic justice of the emirs (Allyn, 1976, pp. 4-9). Essentially, by colonial mandate, these southern immigrants, many of whom were missionary educated, were ruled directly by the British. Because of this relatively privileged status of southerners, some have argued that under Lugard's successors in the North, Girouard and Temple, the primary architect of the sabon gari system, Indirect Rule became a sort of "natural law" that viewed western educated southerners as dangerous elements that would disrupt the stability of the region. These southerners would alter the effectiveness of Indirect Rule by the introduction of "ill digested ideas of liberty and justice" (Ayandele, 1966, p. 516; Olusanya, 1967, p. 244). I have discussed the sabon gari system elsewhere and shown that this "contamination argument" was secondary to the economic considerations of the capitalist firms operating in the area (King, 2003). Though for the British administrators stability, or "law and order," was a primary concern, the real fear of contamination was not from the southern workers and traders in the sabon gari but from the more general expansion of missionaries and, more importantly, formal, missionary-styled education in the region.

Katsina was the preeminent example of the type of educational system that was established by the British and financed by the Native Authorities in the Northern Region. For many years government secondary education in the Protectorate of Northern Nigeria was centered in Katsina. Yet, little attention was paid to the development of western oriented education during the first two decades of British rule. For more than a decade, Katsina held the North's only institution of secondary education. A small primary school was built there in 1909 but it was poorly organized. And, though by 1912 there was also a British School in Kano, most aristocratic families still preferred to send their children to one of the 101 koranic schools (Hull, 1969, pp. 321-326).

In 1915, after becoming Governor General of an amalgamated Nigeria, Lugard called for more grants-in-aid to government schools in the North. However, officials in London did not support this initiative, arguing instead that such grants "... might involve the introduction in mission schools of the European system of education which had tended to 
produce such unsatisfactory results" in the coastal areas of West Africa. Lugard regretted that there had been no cooperation between governmental and missionary educational agencies. It was his belief that ..." by cordial cooperation the government, while setting the standard of efficiency in its own schools, could and should be able to make use of the missions and to so guide and control their methods that they should become an educational agency of value in the country" (HULL 1969, p. 327). However, the Resident of Kano, Palmer, like most of his contemporaries, was less than enthusiastic about the introduction of European, "Christian-tainted" educational programs. Instead he favored the expansion of Muslim education. He argued that if the young Hausa intellectual was not well grounded in his faith, he would be dangerously vulnerable to religious fanaticism which in turn was a threat to stable government"(HULL, 1969, p. 328). Palmer believed "that the Hausa intellectual must not be Europeanized in any way.... Education in the north was designed to shield the student from the Europeanizing tendencies of Southern Nigeria, which was dotted with many Western-oriented missionary schools." And "although by 1915 instruction in government schools was in English, the vernacular and Arabic continued to be encouraged" (HULL, 1969, p. 329).

It was not until Clifford, who replaced Lugard as Governor General in 1919, that indigenous northerners were trained as teachers in the growing number of government supported primary schools. In 1921, Clifford chose Katsina as the site for the first teacher training college in the North because in the precolonial period, it had been a site for higher education in Hausaland. Yet, as Clifford noted when outlining the objectives of the college in 1922:

The students should be subjected to no influences which might tend to make them careless about the observances of their religious duties, forgetful of the customs and traditions of their fellow countrymen, or lacking the respect and courtesy which they owe to.... all who occupy positions of authority... The young man who shows that he is unable to acquire knowledge without becoming arrogant to his fellows, impertinent to his superiors, neglectful of his religion, or scornful of the customs and traditions of his forefathers will not be allowed to remain in this institution (HULL, 1969, $\mathrm{p}$. $335)$.

Clearly, there was little change in the official attitude toward custom and even after Clifford departed in 1925, there was no significant missionary activity in Katsina until the 1930s. After that date, both the college and elementary training centers received funds directly from the government, however, the elementary schools continued to be operated entirely by the Native Authority (HULL, 1969, p. 343).

\section{Custom and Collaboration}

It is clear from the analysis above that custom played a significant role in the articulation of the doctrine of Indirect Rule. Lugard's system was premised on the idea that Africans were fundamentally different from Europeans. Consequently, he believed that growth in Africa should be based on its traditional institutions (Lugard, 1965a, p. xlvii). This was the basis of his dual mandate. However, according to Mamdani (1996), Indirect Rule contained a another duality: two forms of power under a single hegemonic authority in which civil power claimed to protect rights, while customary power pledged to enforce tradition. Rights, such as free association and political representation, were the rights of citizens and not of subjects indirectly ruled by a tribal authority governed by custom. In short, race distinguished citizen from subject. Consequently, subjects had to struggle against both local customary authorities and racial barriers in civil society (Mamdani, 1996, pp. 18-19). Like the colonizer's understanding of the necessity for collaborating with indigenous elites, "the division between citizen and subject, the nonnative and the native," was also an ancient colonial practice. "Specific to Africa, though, was the closeting of the subject population in a series of separate containers, each under the custody of a Native Authority said to be the rightful bearer and enforcer of an age-old custom and tradition" (Mamdani, 1996, p.49).

In Northern Nigeria, the customary authorities were the emirs, stripped of their military power. The traditional officials of the Native Authority were considered "the lowest rung of the colonial administrative ladder." Moreover, as noted above, the British reserved the right to appoint the appropriate person to every position (Mamdani, 1996, p. 55). In the process, custom was robbed of much of its diversity, homogenized, and equated with the boundaries of the tribe --there was no recognition that conflicting views of the customary existed (Mamdani, 1996, p.118). We can return to Katsina for an example. In Katsina, by undermining traditional constraints, the British strengthened the emir's power, while simultaneously making him more dependent on British support. Emir Yero was appointed after Emir Abubakr was deemed "uncooperative" by the British. Yero was a member of the Dallazawa royal family, and was, according to custom, still a legitimate heir to the emirship. Lugard warned him against "any general confiscations of titles and property" and he was also told that "all dismissals and appointments," including those of the royal family that had traditionally been the "kingmakers," had to be approved by "the emir's overlords, the Assistant Resident and his superiors." However, within the first month of his appointment, Yero dismissed seventy three officials, including the royal sons of the ex-emir Abubakr (HULL, 1969, p. 120). Emir Yero simply refused to act as a collaborator. He retreated to his palace and ultimately the British had to resort to a form of direct rule that by-passed the emir and his 
indigenous staff. In fact, the local village heads began to bring both their tax money and grievances directly to the Resident. In the process, administration passed from the emir to the British and in November of 1906, Yero was deposed and later deported (HULL, 1969, pp. 145-147).

Clearly, Indirect Rule was not working well in Katsina. Consequently, Muhammadu Dikko, who was not of royal birth, was appointed as emir by the acting High Commissioner in 1907, without the approval of the traditional aristocracy and without the customary checks and balances that usually attended the process. It became clear to the Fulani that "the Emir was little more than a figurehead" and that resistance to British authority could be "politically disastrous." And Dikko, this "mouthpiece of the British" was greeted "with indignation by nearly everyone" (HULL, 1969, pp. 148-151). However "in accordance with the spirit of the Political Memoranda, British officers were to rule behind the scenes" and attempt to at least keep up the appearance of Hausa-Fulani control. Nevertheless, all appointments to judgeships, district and village headships had to be approved by the British and any administrative appointment could be vetoed by them; they also had the right of judicial review. Moreover, uncooperative officials "were in most cases ultimately deposed." The British also closely supervised tax assessment and carefully checked and periodically audited Native Authority treasury accounts. As a result of this British pressure, Dikko tended to appoint men as village heads to areas where they had no historical connection. Hence by 1916 , nearly $25 \%$ of the village heads in the emirate were not indigenous to the areas that they governed but were either relatives or servants of the emir (HULL, 1969, pp. 221-249).

The North did not undergo any substantial governmental changes after amalgamation in 1914. Northern and Southern Nigeria retained their separate secretariat and department organizations, however, this time each under the control and direction of a Lieutenant Governor. Lugard, in his report to London, clearly stated that his conception was... "that the office of the Lieutenant Governor should be one of recognized executive responsibility, to which should be delegated many of the statutory and executive functions of the Governor-General by a process of decentralization" (Kirk-Greene, 1968, p. 64). In other words, in 1914, Lugard considered that before real administrative unification could take place, the South must accept the North's system of government, develop its own local administration, and embrace the legal framework of Indirect Rule (Okonjo, 1967, pp. 77-78). As noted above, in the South, many of the societies were decentralized states. In the North, states like those on the Bauchi Plateau that had remained recalcitrant within the borders of Caliphate were also direct democracies. It was, consequently, not easy to extend Indirect Rule to these areas. In the North, Lugard solved this problem by importing Fulanis from the Muslim emirates as the Native Authorities, thereby paradoxically extending Fulani authority to include people that they had not been able to conquer (Okonjo, 1967, pp. 104-105). In the South, the British often appointed individuals with prestige in their communities as Warrant Chiefs when no chief existed (Afigbo, 1972b). In both instances, the British focused on maintaining the image of traditional authority, as they increased administrative control and compartmentalized customary law.

A large part of the Civilizing Mission, then, was not only the expansion of Christianity but also the spread of the so called "rule of law." The native courts that dispensed customary law were not just intended to settle disputes; they were to ultimately "shine as beacons of western civilization" (Mamdani, 1996, p. 109). Hence the "repugnancy test" permeates the writings of British officials not only in Nigeria but throughout much of Africa (Mamdani, 1996, p. 117). For example, Lugard when referring to Islam in Northern Nigeria in his Dual Mandate (1965a), states that "[I]f however, any particular form of religion sanctions or enforces acts which are contrary to humanity or good order, the Government intervenes regardless of religious sanctions" (Lugard, 1965a, p.594, italics mine). ${ }^{4}$ It is clear that "the point of the repugnancy test was to reinforce colonial power, not to challenge it." The courts decided whether a particular rule was repugnant largely on an ad hoc basis (Mamdani, 1996, p. 117). Hence, the necessities of internal security—of finding ways to control the masses-- forced the Civilizing Mission in the colonies to quickly become "a law and order obsession" in which the emphasis was more on "power than progress"(Mamdani,1996, p. 50). In short, the necessities of administration and power, more often than not, clearly contradicted the ideals of the Civilizing Mission.

\section{Conclusion}

Even before the British incursion, the Sokoto Caliphate was a highly decentralized polity. The individual emirs did not, however, exclude Christian missionaries; nor did Lugard discourage missionary contact after his conquest of the region. But Lugard realized early on in the formal occupation of Caliphate, that the British treasury and taxpayers would not tolerate the financial burden of direct rule. Since he "could not see the fruits of his conquest lost on the tables of the Treasury Office in London," for Lugard, Indirect Rule was a matter of expediency (HULL, 1969, p. 104).

After conquering Sokoto, Lugard assured the caliph that the practice of Islam would not be restricted in any way under the new regime. Subsequent administrators used this commitment to religious tolerance to exclude Christian missionaries; this exclusion quickly became a hallmark of Indirect Rule in Northern Nigeria. In order to preserve "law and order" and "the rule of law" the British argued that the western Christian education that had spoiled southern Nigerians must not be allowed in the North. Because missionaries preached a doctrine of equality and often did menial 
jobs while attempting to convert the masses, colonial administrators feared that they would erode the prestige of all whites. Consequently, as we saw in our examination of Katsina, the educational system was designed to produce graduates that would not be tempted by the western ways of their southern neighbors and missionary education was not allowed until the 1930s.

Another rationale for this missionary exclusion within the context of Indirect Rule was the preservation of custom-a myopic and ossified view of the customary that flew directly in the face of a Civilizing Mission that was purported to be at the heart of the colonial enterprise. The "traditional" now had to be qualified because it was altered to accommodate British interests. Though local Africans were appointed to the Native Authorities, this was only to maintain the pretense of Indirect Rule. In effect, they had little power or responsibility--the inevitable consequence of what Mamdani (1996) called a system of decentralized despotism. And, as we saw in Katsina, the British even bypassed the precolonial local council of electors and the requirement of royal birth in order to crown an emir whom they were able to manipulate.

In closing, two further points should be emphasized. First, it was not the purpose of this paper to imply that the Civilizing Mission was the appropriate path for European colonialism in Northern Nigeria. Indeed, Lugard's Dual Mandate in British Tropical Africa (1965a) provides us with the basis for a compelling contrary argument: "[L]et it be admitted at the outset that European brains, capital, and energy have not been, and never will be, expended in developing the resources of Africa from motives of pure philanthropy." With this assessment, we can certainly agree. It is his further claim, however, "that Europe is in Africa for the mutual benefit of her own industrial classes, and of the native races in their progress to a higher plane" that is obviously problematic (Lugard, 1965a, p. 617). Second, it is equally important to emphasize that Islamic education and, for that matter, decentralized political systems, should not be considered inherently inferior to western education and notions of representative democracy that focus on the individual to the detriment of the group. The purpose of this paper has been, more simply, to show the incompatibility of and the contradictions inherent in two colonial doctrines--the Civilizing Mission and Indirect Rule --doctrines that could not be applied simultaneously in Northern Nigeria.

\section{References}

Adeleye, R. A. (1971). Power and Diplomacy in Northern Nigeria. London: Longman.

Afigbo, A. E. (1972a). “The Indigenous Political System of the Igbo," Tarikh, 4(2), 13-23.

Afigbo, A. E. (1972b) The Warrant Chiefs: Indirect Rule in Southern Nigeria, 1891-1929. London: Longman.

Allyn, D. E. (1976). “The Sabon Gari System in Northern Nigeria, 1911-40” (unpublished doctoral dissertation). UCLA, USA.

Asante, M. K. (2015). The History of Africa: The Quest for External Security. New York: Routledge.

Ayandele, E. A. (1966). "The Missionary Factor in Northern Nigeria, 1870-1918," Journal of the Historical Society of Nigeria, 3(2), 503-522. Retrieved from http://www.jstor.org/stable/41856710.

Chamberlain, M. E. (2010). The Scramble for Africa. Harlow: Pearson.

Clastres, P. (1977). Society against the state: essays in political anthropology. New York: Zone Books.

DeSt. Croix, G. E. M. (1981). The Class Struggle in the Ancient Greek World: From the Archaic Age to the Arab Conquests. Ithaca: Cornell University Press.

Hull, R. W. (1969). "The Development of Administration in Katsina Emirate Northern Nigeria, 1887-1944" (unpublished doctoral dissertation). Columbia University, USA.

Johnston, H. A. S. (1967). The Fulani Empire of Sokoto. London: Oxford University Press.

King, L. D. (2003). "From Caliphate to Protectorate: Ethnicity and the Colonial Sabon Gari System in Northern Nigeria," Journal of Colonialism and Colonial History, 4(2). HTTP://DX.DOI.ORG/10.1353/cch.2003.0044.

KirkGreene, A. H. M. (Ed.) (1968). Lugard and the Amalgamation of Nigeria-A Documentary Record; being a reprint of the Report by Sir F. D. Lugard on the amalgamation of Northern and Southern Nigeria and administration 1912-1919; together with supplementary unpublished amalgamation reports, and other relevant documents; compiled and introduced by A. H. M. Kirk-Greene. London: Frank Cass \&Co.

KirkGreene, A. H. M. (Ed.). (1965). The Principles of Native Administration in Nigeria, 1900-1947: Selected Documents. London: Oxford University Press.

Last, D. M. (1967). The Sokoto Caliphate. London: Longman.

Lugard, F. D. (1965a). The Dual Mandate in British Tropical Africa. Hamden: Archon Books.

Lugard, F. D. (1965b). Political Memoranda. In A.H.M Kirk-Greene (Ed.) The Principles of Native Administration in 
Nigeria, 1900-1947: Selected Documents, 68-149.

Mamdani, M. (1996).Citizen and Subject: Contemporary Africa and the Legacy of Late Colonialism. Princeton: Princeton University Press.

Northrup, D. (2009). Africa's Discovery of Europe. New York: Oxford University Press.

Okonjo, L.M. (1967). British Administration in Nigeria 1900-1950: A Nigerian View. New York: Nok Publishers.

Olusanya, G. O. (1967). "The Sabon Gari System in the Northern States of Nigeria," Nigeria Magazine, 94, 242-248.

Onimode, B. (1982). Imperialism and Underdevelopment in Nigeria: The Dialectics of Mass Poverty. London: Zed Press.

Rodney, W. (1982). How Europe Underdeveloped Africa. Washington D.C.; Howard University Press.

Temple, C. L. (1968). Native Races and Their Rulers. London: Frank Cass and Co. Ltd.

Wolf, E. (1997). Europe and the People without History. Berkeley: University of California Press.

Notes

1. It was Rudyard Kipling's 1899 poem, The White Man's Burden, originally published in McClure's magazine that captured the spirit of this "Age of Imperialism."

2. When Lugard assumed the office of governor of an amalgamated Nigeria in 1914, the Colonial Office was so enamored of the policy of Indirect Rule, and Lugard's implementation of it in the North, that no one else could be trusted to extend its principles to the South. See Okonjo, 1967, p. xvii.

3. Though northerners were often successful in the South, they played a minor role in the economic life and were almost non-existent in the southern civil service because of their lack of western education. See Olusanya, 1967, p. 247.

4. Only on rare occasions did the British admit that the law also had to reinforce their power: "the Evidence Act in Nigeria...stated that no custom 'contrary to public policy' would be enforced." See Mamdani, 1996, p. 115

\section{(cc) EY}

This work is licensed under a Creative Commons Attribution 3.0 License. 